a condition of waiting equilibrium ready to go on to the changes of pregnancy. There is a certain continuity; 'the end is in the beginning'. Perhaps that concept might inspire physiologist and epidemiologist to work more together to discover whether either medicine or social medicine can do anything more to explain or prevent reproductive failures.

\title{
REFERENCES
}

Barcroft, J. (1944). Proc. Nutr. Soc. 2, I4.

Barcroft, J., Elliott, R. H. E., Flexner, L. B., Hall, F. G., Herkel, W., McCarthy, E. F., McClurkin, T. \& Talaat, M. (1934-5). F. Physiol. 83, 192.

Barnes, A. C. \& Quilligan, E. J. (1956). Amer. F. Obstet. Gynec. 71, 670.

Burwell, C. A. (1954). Fohns Hopk. Hosp. Bull. 95, I 15.

Dieckmann, W. J. \& Pottinger, R. E. (1956). Amer. F. Obstet. Gynec. 71, 596.

Garry, R. C., Sloan, A. W., Weir, J. B. de V. \& Wishart, M. (1954). Brit. Ұ. Nutr. 8, 253.

Garry, R. C. \& Stiven, D. (I935-6). Nutr. Abstr. Rev. 5, 855.

Garry, R. C. \& Wood, H. O. (1945-6). Nutr. Abstr. Rev. 15, 59 I.

Hytten, F. E. \& Duncan, D. L. (1956). Nutr. Abstr. Rev. 26, 855.

Kayser, H. W. (1953-4). Arch. Gynäkol. 184, 385.

Morton, N. E. (1955). Ann. hum. Genet. 20, I25.

Newton, W. H. (1944). Proc. Nutr. Soc. 2, I3.

Romney, S. L., Reid, D. E., Metcalfe, J. \& Burwell, C. S. (1955). Amer. Y. Obstet. Gynec. 70, 79 I.

Seitchik, J. \& Alper, C. (1956). Amer.F. Obstet. Gynec. 71, I165.

Thomson, A. M. (1957). Proc. Nutr. Soc. 16, 45.

Walker, J. \& Turnbull, E. P. N. (1953). Lancet, 265, 3 1 2.

Widdowson, E. M. (1939). Lancet, 237, 640 .

\section{Technique and perspective in clinical and dietary studies of human pregnancy}

\author{
By A. M. Thomson, Obstetric Medicine Research Unit (Medical Research Council), \\ Department of Midwifery, University of Aberdeen
}

Before and during the 1939-45 war, a number of field surveys and feeding experiments seemed to show dramatically, though imprecisely, that a good diet helps to ensure normal pregnancy and childbirth; and our wartime food policy, which gave preferential treatment to pregnant women, was accompanied by a sharp fall in the stillbirth and neonatal death rates. But exact scientific information was, and still is, meagre. In 1946, Garry \& Wood (1945-6) noted the development of 'a more critical attitude, even of disillusionment', contrasting with the earlier optimism. The results of recent clinical and dietary investigation have been persistently barren (Sontag \& Wines, 1947; Hobson, 1948; Macy, Moyer, Kelly, Mack, Di Loreto \& Pratt, 1954; McGanity, Bridgforth, Martin, Newbill \& Darby, I955).

We are thus faced with a dilemma: on the one hand, a not unreasonable belief backed by much cogent evidence that the nutrition of pregnant women must be important, and on the other hand, the failure of survey methods to prove that this is so. I shall try to show that the difficulty is one of technique and of perspective. The analysis that follows is based upon the experience of a research team which 
has been surveying nutritional, social, psychological and clinical factors in human reproduction in Aberdeen for several years. Very little of the dietary material has been published so far, but every statement of fact in this brief 'preview' could be more fully documented than is possible in the space available.

\section{Diet surveys}

The primary aim of a diet survey is to establish quantitatively the composition of diets, and accurate quantitative methods must be used. Grams and milligrams cannot be measured on the basis of question-and-answer rituals (Leitch \& Aitken, 1949-50). To weigh and measure diets is laborious and demands considerable co-operation from subjects, but it is surely better to rely upon accurate measurements from a proportion of subjects than upon unmeasured 'quantities' derived from them all.

There is no sound method of expressing the overall nutritive value of a diet in a single figure or rating, though it is frequently attempted. We have to compare clinical data with the energy value and the intake of each nutrient separately, perhaps obtaining a combined result by the technique of multiple correlation.

The results of a diet survey of pregnant women should portray the nutritive value of diets habitually taken during the particular phase of pregnancy studied. Timing is important, since the dietary habits of subjects suffering temporarily from nausea and other digestive upsets may be atypical. However, even accurate diet-survey data do not give a picture of the nutritional background as a whole-a point which is sometimes overlooked.

\section{Nutritional status}

The nutritional status of a pregnant woman depends more upon her life-experience of diet than upon the nature of the diet she happens to take during pregnancy. One who has been habitually well fed before pregnancy will probably come to little harm on any diet that is not grossly defective, and the stores that protect the mother will also protect the foetus. This may perhaps explain why the severe food shortage in north-west Holland during the early half of 1945 had such slight effects upon birth weights and other phenomena of maternity (Smith, 1947). The effects on pregnancy of deprivation during the Leningrad siege seem to have been much more severe (Antonov, 1947), possibly because the women were less well nourished to begin with. Chronic malnutrition from childhood, not amounting to starvation or deficiency disease, causes depression of growth and impairment of élan vital, probably the result of general depression of physiological processes. In this instance a few months of improved diet during pregnancy will no doubt be beneficial but can scarcely be expected to counteract completely the consequences of nutritional neglect during the formative years.

In attempting to relate the clinical events of pregnancy to the mother's diet we therefore have to consider the past as well as the time of pregnancy. Since it is impossible directly to measure the remote dietary past, reliance must be placed upon the assessment of nutritional status. Unfortunately, we have no reliable biochemical 
or clinical criteria of deficiency states above the level of frank disease (Thomson \& Duncan, 1954). We postulated that ill-nourished girls generally become relatively short and unhealthy women, and vice versa. On this basis, ill-nourished groups will contain more women of small stature and impaired health than well-nourished groups. Boyne \& Leitch (1954) have disposed of the widespread notion that improved nutrition accelerates the rate of growth without increasing the final stature attained.

Height is easily measured. The clinical assessment of general health is unavoidably crude and subjective, but if it is undertaken early in pregnancy the gradings are not biassed by knowledge of subsequent clinical events.

\section{Non-nutritional influences}

Factors other than nutrition introduce many complications. A first pregnancy is nearly always less 'efficient' than the next two or three, and under present conditions in Britain well-nourished primigravidae have on the whole a less satisfactory clinical record than ill-nourished women having second or third babies. In primigravidae, the incidence of difficult labour, stillbirth and inadequate lactation rises with age, especially after 30 years (Baird, 1952; Baird, Walker \& Thomson, 1954; Hytten, 1954). A high proportion of women starting a family when young (under 20) come from the poorest sections of the community, and defects attributable to unsatisfactory nutrition may be masked by the high physiological efficiency of youth. Conversely, women living in good social conditions often postpone childbearing until many years after the attainment of physical maturity and for this reason alone may have unsatisfactory obstetric histories.

Some correlations between nutrition and the clinical hazards of maternity are obscured or eliminated by modern methods of prevention and treatment. For example, if the mother has a contracted pelvis, due to past malnutrition, the risks of difficult labour and of stillbirth may be avoided by Caesarean section. Nutrition may once have had some importance in determining susceptibility to infection, but chemotherapy and the antibiotics have eliminated infection as a major hazard of childbearing.

Complications such as these must be taken into account both in the design of the survey and in the analysis of data. The Aberdeen survey underlines the importance of a thorough understanding of the epidemiology and 'natural history' of obstetric phenomena (Baird \& Thomson, 1954).

I shall now summarize four problems in which we have been interested.

\section{Growth and vitality of the foetus}

The foetus grows by virtue of nutrients derived from the maternal diet or tissues. Growth at the expense of the tissues must result in a net loss of maternal weight and is likely to impair maternal health. The hypothesis that birth weight is influenced by nutrition is favoured by the fact that average birth weights diminish with decline 
in social status. Table I shows that the proportion of low birth weights increases as the energy value of the diet decreases. It would, however, be wrong to conclude that a low-energy diet is an important cause of low birth weight; in all groups the range of birth weights is very wide, and when the data are standardized for maternal social status and height the association becomes smaller and more erratic. Furthermore, low birth weights are similarly associated with low intakes of protein and of most other nutrients. All we can say at present is that the 'true' correlation between birth weight and any measure of diet so far tested is small, the coefficient probably being less than $0 \cdot \mathbf{I}$. The relationships may not be linear. A very low correlation is not necessarily unimportant, since a trivial change of mean birth weight may be accompanied by a significant difference in the prematurity rate (Thomson, 195 I).

Table I. Percentage of babies weighing $6 \frac{1}{2} \mathrm{lb} .(2 \cdot 9 \mathrm{~kg})$ or less born to Aberdeen mothers with different calorie intakes in second half of pregnancy. The values are for first pregnancies, excluding twins

\begin{tabular}{lcccc} 
& \multicolumn{4}{c}{ Mean daily calorie intake (Cal.) } \\
\cline { 2 - 5 } Under 2000 & $2000-2500$ & $2500-3000$ & 3000 and over \\
No. of mothers & I3 1 & 249 & 184 & 87 \\
Percentage of birth weights & 36.6 & $26 \cdot 1$ & $25 \cdot 5$ & $23 \cdot 0$ \\
$6 \frac{1}{2}$ lb. or less & & & &
\end{tabular}

The vitality of the baby is more important than its birth weight and is probably much more readily influenced by maternal nutrition. Unfortunately we have no satisfactory way of measuring the vitality of the newborn baby. Clinical assessment is crude and subjective and is often made more difficult by variations in the nature of labour and the effects of sedatives or anaesthetics given to the mother. Attempts to assess the vigour of sucking and other reflexes have not proved helpful (Hytten, 195I). Very large samples would be necessary in order to correlate death rates with determinations of diet made during pregnancy.

\section{Pre-eclamptic toxaemia}

Pregnant women who gain much weight have a relatively high incidence of preeclampsia and, on an average, take diets of relatively high energy value (Chesley, 1944; Thomson \& Billewicz, I955, I957). Pre-eclampsia may more plausibly be regarded as a disease of overfeeding than of underfeeding, but restriction of calorie intake is a very crude method of prevention because many women who gain much weight during pregnancy do not develop pre-eclampsia and some who gain little fail to avoid it. However, the practice of restricting the maternal weight gain in pregnancy by dietary regulation is widespread. Where it exists, the 'natural' relationship between the energy value of diet, the rate of weight gain and the incidence of pre-eclampsia is obscured; indeed, spurious correlations may be introduced (McGanity et al. 1955). 


\section{Lactation}

Lactation involves a considerable drain upon the nutritional reserves of the mother. Inadequate diets should therefore predispose to lactational failure, or to decline in maternal weight and health if lactation continues. Nevertheless, it is surprisingly difficult to establish nutritional inadequacy as an important cause of lactational failure in these days of popular artificial feeding. The older primigravida is less able to initiate an adequate flow of breast milk and is therefore less likely to initiate breast feeding successfully than the younger, despite the fact that she is usually better nourished. If, however, she starts successfully, she is more likely to continue to breast feed (Hytten \& Thomson, 1955). A recent follow-up study in Aberdeen (Yorston, Hytten \& Thomson, I957) indicates that the very high rate of artificial feeding after the ist month amongst primigravidae from the poorer classes is more often due to lack of desire to breast feed than to lack of ability to maintain lactation. Nevertheless, inadequate milk production and impaired maternal health while lactating have been fairly frequently recorded.

\section{Vital statistics}

Correlations that are so inconspicuous in individuals and small groups as to be difficult to demonstrate even by ad hoc survey methods can, when applied to large populations, produce important changes in vital statistics. The stillbirth rate in England and Wales fell from 38 in 1939 to 28 in 1945 . This great achievement was almost certainly due in the main to improved feeding of pregnant women (Duncan, Baird \& Thomson, 1952). There is no need to postulate a conspicuous association between the clinical histories of mothers and the nutritive value of their diets in order to account for a change taking place over a 6-year period which, put in another way, meant that 97 instead of $96 \%$ of them produced a live baby.

The beneficial effect on vital statistics of good growth and health is more easy to show by survey. Table 2 gives the incidence of prematurity and of perinatal mortality

Table 2. Prematurity and perinatal mortality rates in first legitimate single births of mothers of different heights and physical grades (Aberdeen Maternity Hospital booked patients, I95 I-4)

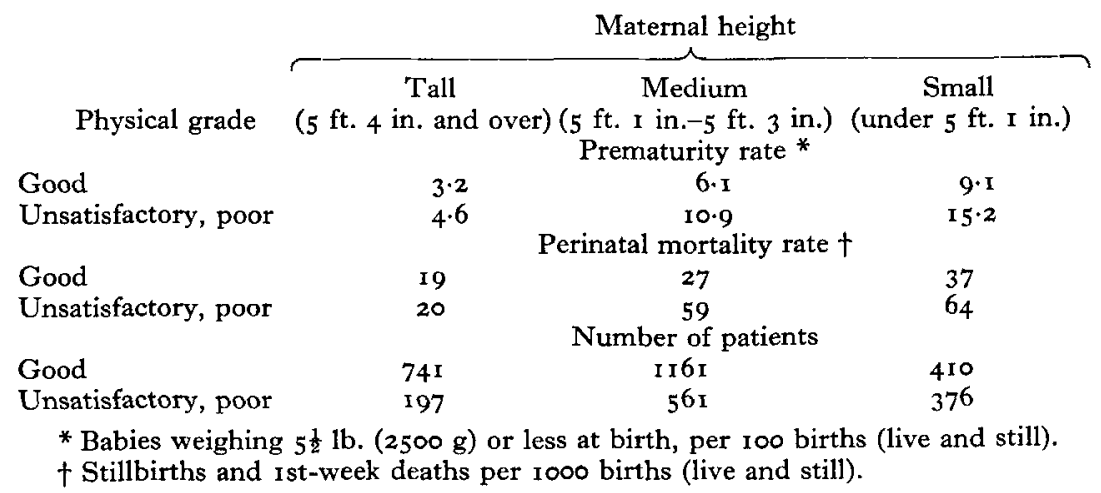

16 (1) 5 
in 3446 primigravidae grouped according to height and general health. In each height group the healthier women had lower rates of prematurity and perinatal mortality. In each grade of health, the rates decrease with rising stature. Small, unhealthy women have a prematurity rate five times as great, and a perinatal death rate three times as great, as tall, healthy women. Illsley (I955) has shown that the proportion of small women as well as the rates of prematurity and perinatal mortality increase steadily with descending order of social status. Bernard (I952) established that small women, and also small men, in Aberdeen have a much higher incidence of contraction and deformity of the pelvic brim than tall, which seems to prove that small adult stature not infrequently results from stunting.

It is difficult to interpret results such as these without reference to nutrition and in our view they confirm its importance.

\section{Conclusion}

In the preceding paper of this symposium, Leitch (1957) discusses the rigidity of outlook induced by constant repetition of a physiological aphorism. In the clinical field we seem still to be haunted by the classic accounts of deficiency disease, which can be prevented or induced by relatively small but highly specific changes of diet. It is all too easy to believe, in defiance of clinical experience and the results of most specific investigations, that the clinical events of pregnancy must be related in some equally sensitive way to variations of diet during pregnancy. None of the common disabilities of pregnancy are deficiency diseases of classic type. Some of them seem to be expressions of inefficient physiological adaptation to pregnancy, due in some measure to chronic and probably non-specific inadequacy or imbalance of diet.

The correlations between food intake during pregnancy and the outcome of pregnancy are so elusive that they are far from easy to demonstrate even by ad hoc survey methods. This is true at least for populations where the average level of nutrition is reasonably high, such as those of Britain and America. Nevertheless, improvement in the diet of pregnant women was responsible for the dramatic reduction of foetal mortality in Britain during the recent war, and there is no reason to think that further improvement is impossible or that the effort would be unrewarding. Again, there is ample confirmation of the common-sense supposition that well-fed girls have a much better chance than those who are ill-fed of becoming well-grown and healthy mothers and of having an uncomplicated pregnancy and labour. A very high standard of nutrition amongst infants, children and probably also of adolescents is therefore essential to healthy childbearing. It cannot be achieved without assiduously educating and helping mothers to take good diets themselves.

In the absence of frank deficiency disease survey methods are of little value for establishing the effects on physiological efficiency-on health-of varying the level of intake of any particular food or nutrient. The 'recommended allowances' for pregnancy depend more upon observation of the diets ordinarily taken by healthy pregnant women with a good reproductive performance, than upon intimate knowledge of the physiological effects of the nutrients involved. These allowances are, therefore, empirical and practical rather than physiological standards. As guides 
to policy they have been amply justified by experience. Yet, in these times of economic stringency, the policy-makers may wish to know whether, for example, the provision of a particular vitamin concentrate to pregnant women can safely be discontinued. Survey data will not provide an answer except in terms of current intake levels and standards. A more precise answer must await the acquisition of more detailed physiological knowledge, or must be obtained ad hoc by means of a carefully controlled feeding experiment-an undertaking even more difficult than a field survey.

The Aberdeen inquiry was partly supported by grants from the Secretary of State for Scotland, on the recommendation of the Advisory Committee on Medical Research. I wish to express the gratitude of the research team.

\title{
REFERENCES
}

Antonov, A. N. (1947). F. Pediat. 30, $25^{\circ}$.

Baird, D. (1952). Amer. F. Obstet. Gynec. 63, 1200.

Baird, D. \& Thomson, A. M. (1954). Gynaecologia, 138, 266.

Baird, D., Walker, J. \& Thomson, A. M. (1954). F. Obstet. Gynaec., Brit. Emp., 6r, 433.

Bernard, R. M. (1952). Edinb. Med. F. 59, Proc. Edinb. Obstet. Soc. p. I.

Boyne, A. W. \& Leitch, I. (I954). Nutr. Abstr. Rev. 24, 255.

Chesley, L. C. (1944). Amer. F. Obstet. Gynec. 48, 565.

Duncan, E. H. L., Baird, D. \& Thomson, A. M. (I952). F. Obstet. Gynaec., Brit. Emp., 59, 183.

Garry, R. C. \& Wood, H. O. (1945-6). Nutr. Abstr. Rev. 15, 59x.

Hobson, W. (1948). F. Hyg., Camb., 46, 198.

Hytten, F. E. (I95 I). Arch. Dis. Child. 26, 477.

Hytten, F. E. (1954). Brit. med. Y. ii, 844.

Hytten, F. E. \& Thomson, A. M. (1955). Brit. med. F. ii, 232.

Illsley, R. (1955). Brit. med.F. ii, 1520.

Leitch, I. (1957). Proc. Nutr. Soc. 16, 38.

Leitch, I. \& Aitken, F. C. (I949-50). Nutr. Abstr. Rev. 19, 507.

Macy, I. G., Moyer, E. Z., Kelly, J. H., Mack, H. C., Di Loreto, P. C. \& Pratt, J. P. (1954). F. Nutr. 52, Suppl. x.

McGanity, W. J., Bridgforth, E. B., Martin, M. P., Newbill, J. A. \& Darby, W. J. (1955). 7. Amer. diet. Ass. 3I, 582 .

Smith, C. A. (1947). F. Pediat. 30, 229.

Sontag, L. W. \& Wines, J. (r947). Amer. J. Obstet. Gynec. 54, 994.

Thomson, A. M. (I95 I). Brit. $\mathcal{F} . N u t r .5$, 58 .

Thomsan, A. M. \& Duncan, D. L. (1954). Nutr. Abstr. Rev. 24, x.

Thomson, A. M. \& Billewicz, W. Z. (1955). Proc. Nutr. Soc. 14, v.

Thomson, A. M. \& Billewicz, W. Z. (1957). Brit. med. $\mathcal{~ . ~ ( I n ~ t h e ~ P r e s s . ) ~}$

Yorston, J., Hytten, F. E. \& Thomson, A. M. (1957). In preparation.

\section{Placental transmission and foetal nutrition}

\author{
By E. C. Amoroso, Royal Veterinary College and Hospital, London
}

Text for publication not received. 